This pdf of your paper in Medicine and Healing in the Ancient Mediterranean World belongs to the publishers Oxbow Books and it is their copyright.

As author you are licenced to make up to 50 offprints from it, but beyond that you may not publish it on the World Wide Web until three years from publication (September 2017), unless the site is a limited access intranet (password protected). If you have queries about this please contact the editorial department at Oxbow Books (editorial@oxbowbooks.com). 


\section{An offprint from \\ MEDICINE AND HEALING IN THE ANCIENT MEDITERRANEAN WORLD}

including the Proceedings of the International Conference with the same title, organised in the framework of the Research Project 'INTERREG IIIA: Greece-Cyprus 2000-2006, Joint Educational and Research Programmes in the History and Archaeology of Medicine, Palaeopathology and Palaeoradiation'

and

the 1st International CAPP Symposium

'New Approaches to Archaeological Human remains in Cyprus'

Hardcover Edition: ISBN 978-1-78297-235-8

Digital Edition: ISBN 978-1-78297-236-5

Edited by

Demetrios Michaelides

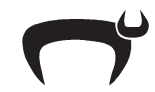

(c) Oxbow Books 2014

Oxford \& Philadelphia 
Published in the United Kingdom in 2014 by

OXBOW BOOKS

10 Hythe Bridge Street, Oxford OX1 2EW

and in the United States by

OXBOW BOOKS

908 Darby Road, Havertown, PA 19083

(C) Oxbow Books and the individual authors 2014

Hardcover Edition: ISBN 978-1-78297-235-8

Digital Edition: ISBN 978-1-78297-236-5

A CIP record for this book is available from the British Library

Library of Congress Cataloging-in-Publication Data

Medicine in the Ancient Mediterranean World (Conference) (2008 : Nicosia, Cyprus), author.

Medicine and healing in the ancient Mediterranean world : including the proceedings of the international conference with the same title, organised in the framework of the Research Project INTERREG IIIA : Greece/Cyprus 2000/2006, Joint Educational and Research Programmes in the History and Archaeology of Medicine, Palaeopathology, and Palaeoradiation, and the 1st International CAPP Symposium "New Approaches to Archaeological Human Remains in Cyprus" / edited by Demetrios Michaelides.

p. ; cm.

Includes bibliographical references.

ISBN 978-1-78297-235-8

I. Michaelides, Demetres, editor. II. International CAPP Symposium "New Approaches to Archaeological Human Remains in Cyprus" (1st : 2008 : Nicosia, Cyprus), author. III. Biomedical Sciences in Archaeology (Conference) (1st : 2008 : Erakleion, Greece), author. IV. Title.

[DNLM: 1. History of Medicine--Mediterranean Region--Congresses. 2. Archaeology--Mediterranean Region--Congresses. 3. History, Ancient-

-Mediterranean Region--Congresses. 4. History, Medieval--Mediterranean Region--Congresses. WZ 70 GM35]

R135

610.938--dc23

\section{0}

All rights reserved. No part of this book may be reproduced or transmitted in any form or by any means, electronic or mechanical including photocopying, recording or by any information storage and retrieval system, without permission from the publisher in writing.

Printed in the United Kingdom by Berforts Information Press Ltd, Eynsham, Oxfordshire

For a complete list of Oxbow titles, please contact:

\section{UNITED KINGDOM}

Oxbow Books

Telephone (01865) 241249, Fax (01865) 794449

Email: oxbow@oxbowbooks.com

www.oxbowbooks.com

\section{UNITED STATES OF AMERICA}

Oxbow Books

Telephone (800) 791-9354, Fax (610) 853-9146

Email: queries@casemateacademic.com

www.casemateacademic.com/oxbow

Oxbow Books is part of the Casemate Group

Front cover: Mosaic of Saint Demetrios and an angel (before the 7th century AD). Basilica of Saint Demetrios, Thessaloniki (photo: 9th Ephoreia of Byzantine Antiquities).

Marble tombstone of the Athenian physician Jason (2nd century AD), Athens (photo: British Museum)

Back cover: Rodon (rose), illumination from mid-14th century manuscript (Padua, Biblioteca del Seminario, 194, f.134 r)

Roman limestone ex-voto of pair of eyes, of unknown origin, in the Cyprus Museum, Nicosia (photo: A. Koutas)

Wearing the plantago as a necklace to cure the headache (Codex Vindobonensis 93, f. $10 \mathrm{v}$ ). 


\section{Contents}

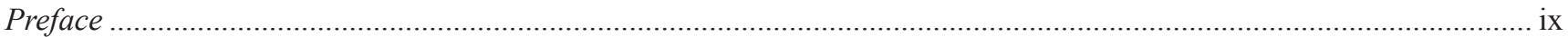

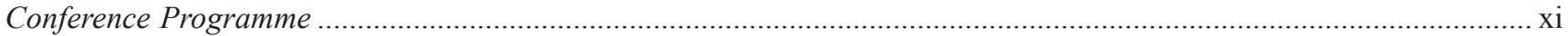

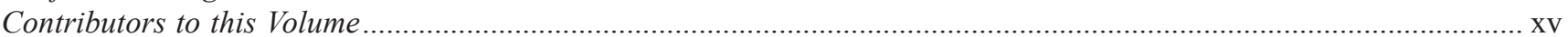

\section{PART I - MEDICINE AND ARCHAEOLOGY}

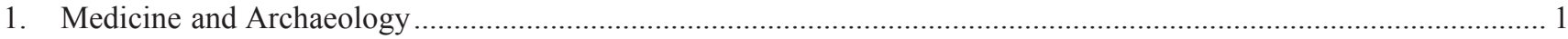

Athanasios A. Diamandopoulos

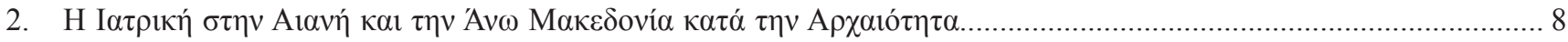

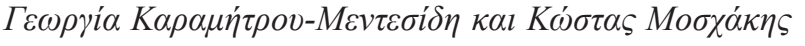

Medicine in Aiane and Upper Macedonia during Antiquity

Georgia Karamitrou-Menesidi and Kostas Moschakis

3. Ancient Greek Votives, Vases and Stelae Depicting Medical Diseases................................................................ 24

Stefanos Geroulanos

4. The Anatomical Ex-votos of Hellenistic and Roman Cyprus .......................................................................... 30

Demetrios Michaelides

PART II - MEDIA

5. Providing Online Access to Graeco-Roman Medicine: BIUM's Electronic Corpus of Ancient Physicians.

Guy Cobolet

PART III - THE AEGEAN

6. Healers and Medicines in the Mycenaean Greek Texts ....................................................................................4

Robert Arnott

7. Health and Healing on Cretan Bronze Age Peak Sanctuaries ........................................................................ 54

Christine Morris and Alan Peatfield

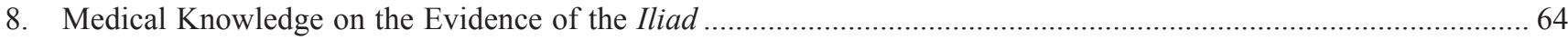

Tamar Sukhishvili

\section{PART IV - MEDICAL AUTHORS/SCHOOLS OF MEDICINE}

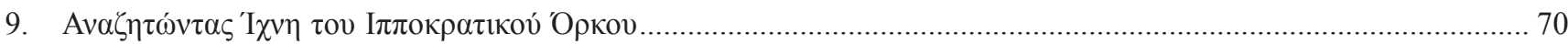

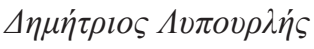

Searching for Traces of the Hippocratic Oath

Demetrios Lypourlis

10. Echoing Hippocrates: Aspects of Genre Intertextuality in the 5th Century BC.

Athina Papachrysostomou and Georgios Gazis

11. Ancient Medicine and Philosophy: a Philosopher's Perspective

Eleni M. Kalokairinou

12. The Threshold of Pain: the Literary Embodiment of Pain and its Cognates in the

Hippocratic Corpus 
13. Le Traité de Galien De pulsibus ad tirones : Pratique Médicale et Représentation du Corps Humain.

Dina Bacalexi

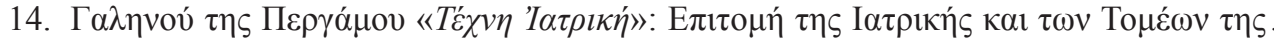

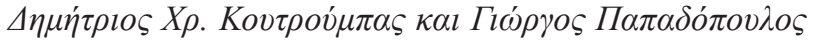

The 'Art of Medicine' of Galen of Pergamon: Epitome of Medicine and its different Fields

Dimitrios Chr. Koutroumpas and Giorgos Papadopoulos

15. An Episode in the Historiography of Malaria in the Ancient World

Philip van der Eijk

16. Medical Dialogue in the Books on Dietetics in the De medicina: Celsus Taking Account of the

Patient as a Friend and Individual.

Aurélien Gautherie

17. The Contribution of the 4th Century North African Physician, Helvius Vindicianus

Louise Cilliers

PART V - SURGERY

18. Back to Basics: Surgeons' Knives in the Roman World.

Ralph Jackson

19. Alexander's Wounds as a Paradigm for War Surgery Alfredo Musajo Somma

20. Surgery in Byzantium.

Stefanos Geroulanos, Charalambos V. Panaretos and Efterpi Lyberopoulou

21. Plastic Surgery of the Face in Byzantine Times....

Marios Papadakis, Evangelos Sfakiotakis, Marios Fragakis, Constantinos

Trompoukis, Maria Fragaki, Moschoula Leivadara and Andreas Manios

\section{PART VI - MEDICAMENTS AND CURES}

22. The Headache Remedies of the Pseudo-Apuleius. A Modern Reappraisal

Giorgio Zanchin

23. Compound Medicines in Antiquity: a First Approach

Alain Touwaide

24. Lemnian Earth, Alum and Astringency: a Field-based Approach

Effie Photos-Jones and Allan J. Hall

25. Ancient Desires to Shape Progeny: the Role of Vision and Soul in Greek and Jewish Sources

of Late Antiquity.

Ohr Y. Margalit and Chariklia Tziraki-Segal

26. Medicine and Spas in the Roman Period: the Role of Doctors in Establishments with Mineral-

Medicinal Waters

Silvia González Soutelo

PART VII - SKELETAL REMAINS

27. Health Care and Survival of a Child with Cranial Trauma at Augusta Emerita (Mérida, Spain)

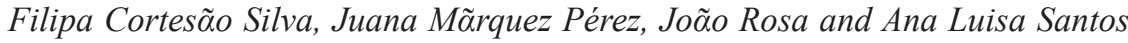

28. A Multidisciplinary Approach for the Study of the 11th-15th century AD Human Skeletal

Remains from Palaion Demarheion, Nicosia, Cyprus.

Popi Chrysostomou and Yiannis Violaris 


\section{1st International CAPP Symposium 'New Approaches to Archaeological Human remains in Cyprus'}

29. Introduction to the Cyprus Ancient Population Project (CAPP) and the First CAPP Symposium Kirsi O. Lorentz

30. My Side of the Mountain: Initial Colonisation and Biological Regionalism on Cyprus through the Neolithic and Chalcolithic

Zissis Parras

31. Ante-mortem Tooth Loss in Chalcolithic Populations of Cyprus: Comparisons between Cemetery and Settlement

Kirsi O. Lorentz

32. A Preliminary Look at the Health Status of Chalcolithic Populations: Inferences from Linear Enamel Hypoplasias Michelle Gamble and Kirsi O. Lorentz

33. A Preliminary Analysis of Trauma Patterns in Early Christian Cyprus

Sherry C. Fox, Ioanna Moutafi, Eleanna Prevedorou and Despina Pilides

\section{PART VIII - ASKLEPIOS AND INCUBATION}

34. The Development of the Practice of Incubation in the Ancient World Juliette Harrisson

35. The Authority of Physicians as Dream Interpreters in the Pergamene Asclepieion Ido Israelowich

36. Asclepius the Divine Healer, Asclepius the Divine Physician: Epiphanies as Diagnostic and Therapeutic Tools Georgia Petridou

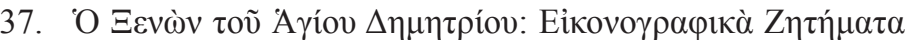
308

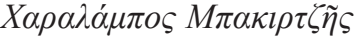

The Hostel of Saint Demetrios: Iconographic Issues

Charalambos Bakirtzis

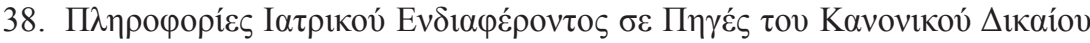

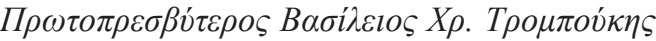

Information of Medical Interest in Sources of Common Law

Father Vasileios Chr. Trompoukis

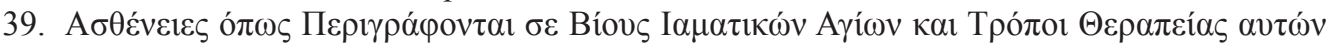

$\Delta \eta \dot{\mu} \tau \rho \alpha \Pi \alpha \pi \alpha \ddot{\omega} \omega \alpha \dot{v v o v}$

Diseases as described in the Lives of Healing Saints and the Means of their Treatment

Demetra Papaioannou

PART IX - BYZANTINE, ARAB AND MEDIEVAL SOURCES

40. The Role of the Egyptian Sea and Land Routes in the Justinian Plague: the Case of Pelusium

Costas Tsiamis, Effie Poulakou-Rebelakou and George Androutsos

41. Du Diagnostic différential aux Thérapies prudentes : Le traité de la rougeole et de la variole de Râzî

Mehrnaz Katouzian-Safadi and Jean-Marc Bonmatin

42. The Ancient Background of Witelo's Theory of Vision

Maria-Magdalena Weker 


\section{Contributors to this volume}

George Androutsos

History of Medicine

Athens Medical School

University of Athens

Athens

Greece

Email: lyon48@otenet.gr

RoBert ARnOTT

Green Templeton College

University of Oxford

UK

Email: Robert.Arnott@medsci.ox.ac.uk

Dina BACALEXI

CNRS Centre Jean-Pépin (UPR_76)

L'Année Philologique

7 rue Guy-Môquet

F-94801 Villejuif Cedex

France

Email: bacalexi@vjf.cnrs.fr

Charalambos BaKirtzis

Anastasios G. Leventis Foundation

P.O. Box 2543

40, Gladstonos Street

1095 Nicosia

Cyprus

Email: charalambosb@yahoo.gr

JeAn-Marc Bonmatin

Centre de Biophysique Moléculaire - CNRS

Rue Charles Sadron

45071 Orléans Cedex 02

France

Email: bonmatin@cnrs-orleans.fr

Popi Chrysostomou

Cyprus Missing Persons Forensic Laboratory

Nicosia

Cyprus

Email: kaliopi05@gmail.com
Louise Cilliers

Department of Classics

University of the Free State

P.O. Box 339

Bloemfontein 9301

South Africa

Email: louise.cilliers@mweb.co.za

Guy Cobolet

Bibliothèque Interuniversitaire de Santé

12 rue de l'Ecole de Médecine

75006 Paris

France

Email: guy.cobolet@biusante.parisdescartes.fr

Filipa Cortesão Silva

Department of Life Sciences and CIAS

University of Coimbra

Apartado 3046

P-3001-401 Coimbra

Portugal

Email: filipacortesao@hotmail.com

Athanasios Diamandopoulos

St Andrew's State Hospital

1, Tertsidou Street

Patras

Greece

Email: tdiamandopoulos@yahoo.com

Sherry C. Fox

Wiener Laboratory

American School of Classical Studies at Athens

54, Souidias Street

Athens GR106-76

Greece

Email: sfox@ascsa.edu.gr 
Maria Fragaki

Department of Surgical Oncology

University General Hospital

Heraklion

Greece

Marios Fragakis

Department of Dentistry

University General Hospital

Heraklion

Greece

Michelle Gamble

School of Historical Studies

Armstrong Building

Newcastle University

Newcastle-upon-Tyne NE1 7RU

UK

Email: michelle.gamble@ncl.ac.uk

Aurélien Gautherie

23 rue de Kembs

67100 - Strasbourg

France

Email: agautherie@yahoo.fr

Georgios Gazis

27, Matrozou Street

14121 Neo Irakleio

Athens

Greece

Stefanos Geroulanos

University of Zurich

President, International Hippocratic Foundation

4, Papastratou Street

Kifissia

Athens 14562

Greece

Email: stgeroulanos@gmail.com

Silvia GonzÁles Soutelo

Universidade di Santiago de Compostela

Facultade de Xeografía e Historia

Universidade de Vigo

Campus Universitario As Lagoas, $\mathrm{s} / \mathrm{n}$

32004 Ourense

Spain

Email: silviatui2004@yahoo.es
Allan J. Hall

Department of Archaeology

University of Glasgow

Glasgow G12 QQ

Scotland

UK

Email: allan.hall@me.com

JulietTe HARrisson

Institute of Archaeology and Antiquity

University of Birmingham

Birmingham B15 2TT

UK

Email: Juliette.Harrisson@staff.newman.ac.uk

IDO ISRAELOWICH

Department of Classics and History

Tel Aviv University

Tel Aviv

Israel

Email: ido0572@post.tau.ac.il

RALPH JACKSON

Curator of Romano-British Collections

Department of Prehistory and Europe

British Museum

Great Russell Street

London WC1B 3DG

UK

Email: rjackson@thebritishmuseum.ac.uk

Eleni M. Kalokairinou

Aristotle University of Thessaloniki

Department of Philosophy and Education

University Campus

54124 Thessaloniki

Greece

E-mail: elenikal132@yahoo.gr

Nicholas A. E. Kalospyros

Department of Philosophy and History of Science

The National and Kapodistrian University of Athens

Athens

Greece

Email: nkalospy@phs.uoa.gr 
Georgia Karamitrou-Mendesidi

30th Ephorate of Prehistoric and Classical Antiquities

Archaeological Museum of Aiani

P.O. Box 50004

Aiani Kozanis

Greece

Mehrnaz Katouzian-SAfadi

CNRS- Laboratoire SPHERE - CHSPAM - UMR 7219

Université Denis Diderot

75205 CEDEX 13 Paris

France

Email: katouzian.safadi@orange.fr

Demetrios C. Koutroumpas

Post-Doctoral Researcher

School of DentistryNational Kapodistrian University of Athens

Dem. Liouni 8

Keratea 19001

Greece

Email:dkoutrou@gmail.com

Moschoula Leivadara

Department of Surgical Oncology

University General Hospital

Heraklion

Greece

DEMETRIOS LyPOURLIS

Arch. Oikonomide 1

54636 Thessaloniki

Greece

Email: dlipourlis@yahoo.gr

Kirsi O. LORENTZ

Science and Technology in Archaeology Research Centre The Cyprus Institute

Guy Ourisson Bldg. Athalassa Campus

P.O. Box 27456

1645 Nicosia

Cyprus

Email: k.o.lorentz@cyi.ac.cy

EFTERPI LyBEROPOULOU

Intensive Care Unit

Onassis Cardiac Surgery Center

Syngrou 354

Athens 176-74

Greece

Email: efterpi.lyberopoulou@gmail.com
Andreas Manios

Department of Surgical Oncology

Univertsity General Hospital

Heraklion

Greece

OHr Y. Margalit

Levinsky College of Education

Tel Aviv

Israel

Email: ohr.margalit@gmail.com

Juana Márquez Pérez

Consorcio Ciudad Histórico-Artística y Arqueológica de Mérida

C/ Reyes Huertas, 4

Mérida-Badajoz 06800

Spain

Email: juana@consorciomerida.org

Demetrios Michaelides

Archaeological Research Unit

University of Cyprus

Kallipoleos 75

Nicosia 1678

Cyprus

Email: d.michaelides@ucy.ac.cy/ dmichael@spidernet.com.cy

Christine Morris

Department of Classics and Centre for Mediterranean and Near Eastern Studies

Trinity College Dublin

Dublin 2

Ireland

Email: cmorris@tcd.ie

Kostas Moschakis

30th Ephorate of Prehistoric and Classical Antiquities

Archaeological Museum of Aiani

P.O.B. 50004

Aiani Kozanis

Greece

Email: con.mosch@yahoo.gr

IOANNA MoutAFI

Department of Archaeology

University of Sheffield

Sheffield

UK 
Alfredo Musajo Somma

Departimento ACTI

Università degli Studi di Bari

Via Calefati, 190

70122 Bari

Italy

Email: musajosomma@libero.it

Charalambos V. Panaretos

204-206, Corinthou Street

Patras 26221

Greece

Email: panaretos.ch@gmail.com

Athina PaPachrysostomou

Open University of Greece

3, Valtetsiou Street

15231 Kato Chalandri

Athens

Greece

Email: athina.papachrysostomou@uclmail.net

Marios Papadakis

Department of Surgical Oncology

University General Hospital

Heraklion, Voutes 71110

Greece

Email: marios_papadakis@yahoo.gr

Giorgos Papadopoulos

School of Medicine

National Capodistrian University of Athens

Athens

Greece

Dimitra Papaioannou

8th Ephorate of Byzantine Antiquities

Gorgopotamou 18

45221 Ioannina

Greece

Email: dipapaioannou@culture.gr

ZISSIS PARAS

2528 Kingsberry Cres.

Mississauga

Ontario L5B 2K5

Canada

Email: zparras@hotmail.com

Alan Peatfield

School of Archaeology

University College Dublin

Dublin 4

Ireland

Email: alan.peatfield@ucd.ie
Georgia Petridou

Department of Classics and Ancient History

University of Exeter

Amory Building

Rennes Drive

EX4 4RJ Exeter

Devon

UK

Email: G.Petridou@ex.ac.uk

Euphemia Photos-Jones

Analytical Services for Art and Archaeology (Ltd)

and

Department of Archaeology

University of Glasgow

Glasgow G12 QQ

Scotland

UK

Email: effie@sasaa.co.uk

Despina Pilides

Department of Antiquities

Ministry of Communications and Works

Nicosia

Cyprus

Email: despo_pilides@hotmail.com

Effie Poulakou-Rebelakou

History of Medicine

Athens Medical School

University of Athens

Greece

Email: efpoulrebel@med.uoa.gr

Eleni Anna Prevedorou

School of Human Evolution and Social Change

Arizona State University

Tempe, Arizona

USA

Jõ̃o Rosa

Department of Pediatrics

Hospital de Faro - E.P.E.

Rua Leão Penedo

8000-386 Faro

Portugal

Email: rosa.joao@gmail.com

Ana Luisa Santos

Department of Life Sciences and CIAS

University of Coimbra

Apartado 3046

P-3001-401 Coimbra

Portugal

Email: alsantos@antrop.uc.pt 
Evangelos Sfakiotakis

Department of Plastic Surgery

Thriassio General Hospital

Magoula

Athens

Greece

TAmar SukHishviLI

Faculty of Humanities and Cultural Studies

Ilia Chavchavadze State University

0186 Tbilisi

Georgia

Email: tasukhi@yahoo.com

Alain Touwaide

Smithsonian Institution

Washington, DC

USA

Email: atouwaide@hotmail.com

Constantinos Trompoukis

Department of History of Medicine and Medical Ethics

University of Crete

Heraklion

Greece

Email: trompoukis@med.uoc.gr

Father Vasileios Chr. Trompoukis

40, Krystalli Street

Arta 47100

Greece

Email: vtrompoukis@hol.gr

Costas TSIAmis

History of Medicine

Medical School

University of Athens

Athens

Greece

Email: ctsiamis@med.uoa.gr
Chariklia Tziraki-Segal

Hebrew University

Ein Kerem

Israel

Email: tziraki@gmail.com

PhILIP VAN DER EIJK

Humbolt University

Berlin

Germany

Email: philip.van.der.eijk@staff.hu-berlin.de

YianNIS Violaris

Department of Antiquities

Ministry of Communications and Works

Limassol

Cyprus

Email: violarisyian@yahoo.gr

Maria-Magdalena WeKer

Institute of Philosophy

Cardinal Stefan Wyszynski University

Warsaw

Poland

Email: m.weker@uksw.edu.pl

Giorgio Zanchin

Headache Centre

Department of Neurosciences

Padua University Medical School

Via Giustiniani 5

I 35128 Padova

Italy

Email: giorgio.zanchin@unipd.it 


\title{
27. Health Care and Survival of a Child with Cranial Trauma at Augusta Emerita (Mérida, Spain)
}

\author{
Filipa Cortesão Silva, Juana Márquez Pérez, João Rosa \\ and Ana Luísa Santos
}

Among the individuals recovered in a funerary area south of Augusta Emerita (Mérida, Spain) was a child who was about 3 years old. According to the grave goods, this burial is dated to the second half of the 1 st to the 2 nd century $A D$. The observation of the skull revealed a severe traumatic lesion affecting the frontal and right zygomatic areas, with signs of bone remodelling, also visible on images produced by the Three-Dimensional Computed Tomography. The consequences of the lesion on the child's health and the health assistance that allowed his/her survival for some time are discussed. According to literature, the Romans had the medical knowledge, namely surgery, to deal with this type of problem.

\section{Introduction}

Our knowledge of the history of medicine can benefit from the study of prehistoric and historic human skeletons. This type of material can reveal medical practices in addition to information about the history of diseases. Trauma is among the pathologies that can be analysed and is the key issue of this work. According to Cook and Powell (2006) the interdisciplinary study of trauma began in the last decades, with aspects such as frequency of fractures, their causes and possible treatments among the obtained data.

In paleopathological literature the diagnosis on non-adults is rare due to the difficulties of identifying these lesions in children and the lack of success in examining children for such pathology (Lewis 2007). However, in the past, as today, fractures in childhood may have been common (Roberts 2000).

Most fractures observed in children from multiple periods in the past are located on the skull, limbs, clavicles, or the ribs (e.g. Lewis 2007). Among the cranial fractures reported, Lewis (1999, in Lewis 2007) documented three cases of head injury (blunt force) in rural Wharram Percy (late medieval England). In one of these cases, the child, who was 5 years old, had no evidence of healing suggesting a subdural haematoma and subsequent death. Furthermore, there are also several bibliographic references to skull lesions observed in infants and children caught up in warfare and massacres at different places and dates (Lewis 2007). Regarding healed skull fractures, only a few cases were noticed. Rühli et al. (2002) studied a child cranial vault fragment found at Vilmar-Weyer, Germany, from the early medieval period, which presents a semicircular lesion with signs of bone remodelling on its edges. A Multislice Computed Tomography confirmed the diagnosis. Another example concerning healed fractures on a right parietal bone was found on a 2 year old girl from the 4th century AD in Lisieux, Normandy (Blondiaux et al. 2002). These authors interpreted the skull lesions as a result of child abuse.

Our research concerns a case which comes from a funerary area of the colony of Augusta Emerita, the capital of Lusitania. This Roman province extended over a region that today corresponds to the southern territories of Portugal and Spain. Augusta Emerita, now called Mérida, is a city located in the Extremadura province, in Spain. This paper aims to describe a cranial case of trauma on a Roman child, its effects on the child's health and the possible health assistance that allowed his or her survival.

\section{Material and methods}

In 2005, Grave A 33 (archaeological intervention number 5036) situated in a funerary area located in the south of 


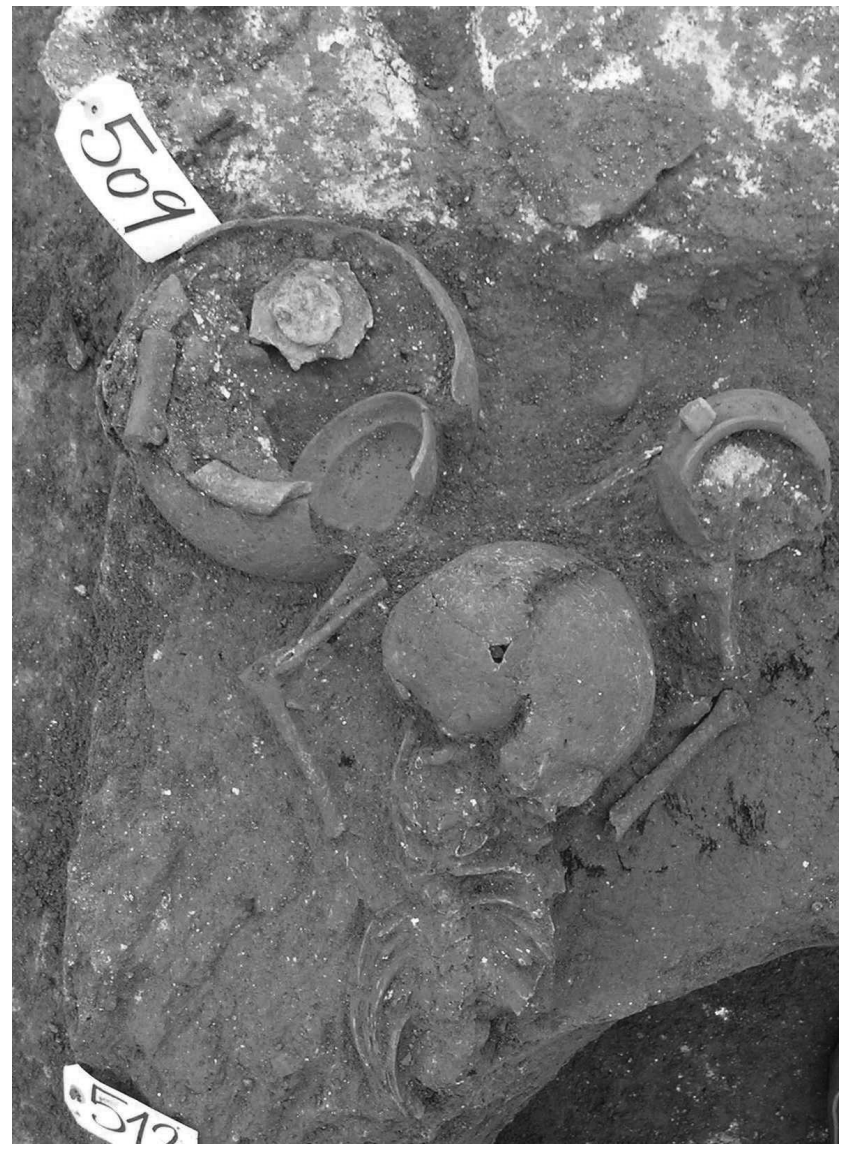

Fig. 27.1. Child burial in situ in Grave A 33 at Augusta Emerita, with the head facing north and the face lying on its left side. Note that the arms are raised up, one on each side of the head

Augusta Emerita was excavated by Juana Márquez Pérez. According to the grave goods - two ceramic vessels - this grave dates to the second half of the 1 st to the 2nd century AD. Among the individuals recovered (Silva et al. 2008) there is a child (stratigraphic unit number 325) inhumed in supine position, with the head facing north and the face lying on the left side (Fig. 27.1). Only the skull, thorax and upper limbs were present. The arms were raised up, one on each side of the head, corresponding to an atypical burial body posture. The pelvis and the lower limbs of this individual were not preserved, probably due to the violation of the nearby burial A 34 .

Later, in 2008, this individual was cleaned and studied in the laboratory. Since the skull was fragmented it was necessary to perform its reconstruction. The age at death was estimated based on Ubelaker (1989) and Scheuer and Black (2000). Measurements of the long bones were taken with a Mitutoyo digital caliper (precision $0.01 \mathrm{~mm}$ ). The skull was radiographed (GE Healthcare, Senographe DC, reference 5131764-7-1PT) and submitted to Three-
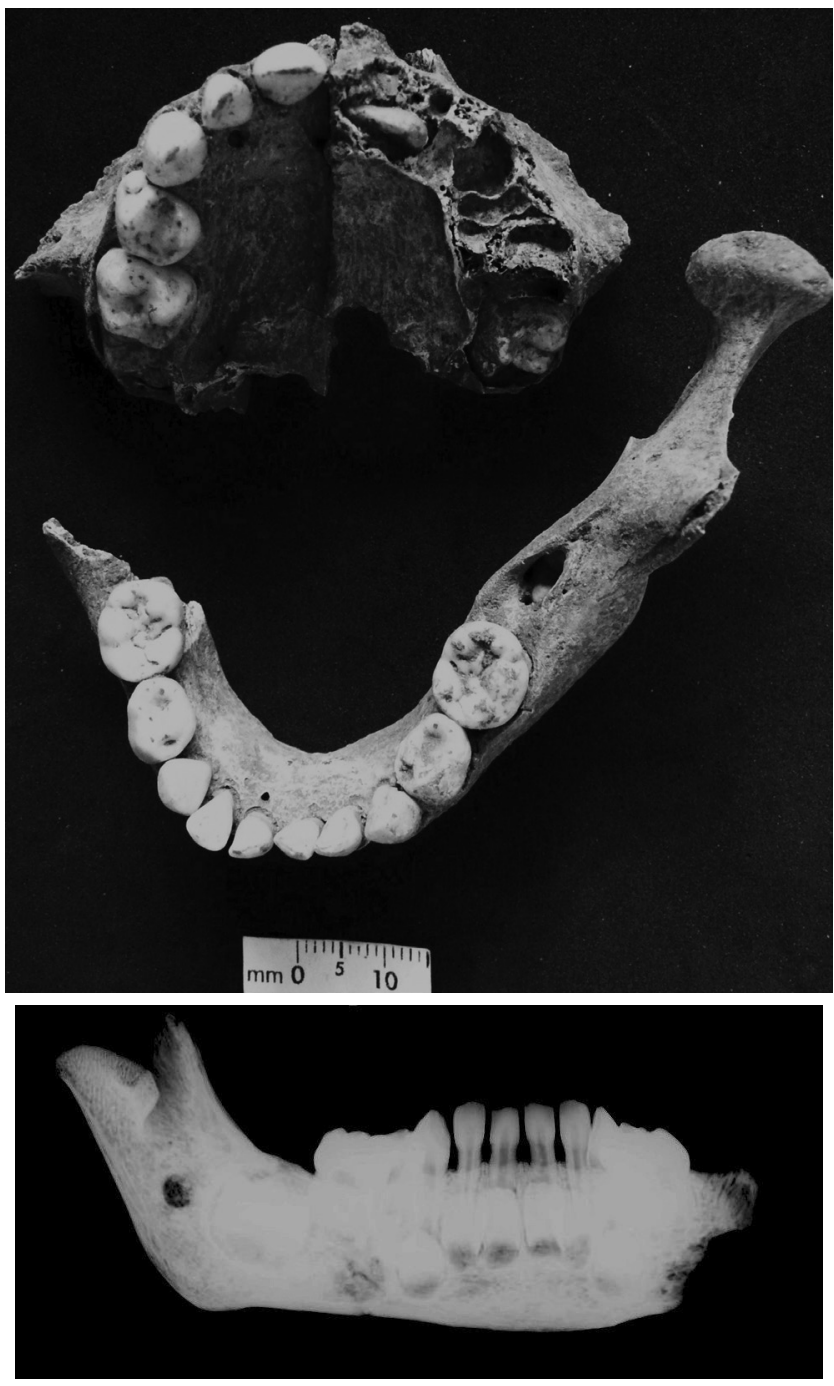

Fig. 27.2. Maxilla and mandible of the child illustrating the tooth erupted. A radiograph of the mandible where the dental development can be seen

Dimensional Computed Tomography (3D-CT), using a Siemens Somatom Volume Zoom 4 VA47C.

\section{Description of the child}

According to the sequence of teeth formation and eruption (Ubelaker 1989), this individual was 3 years \pm 12 months old (Fig. 27.2). However, long bone lengths indicated an age at death between $1 \frac{1}{2}$ and 3 years (Table 27.1).

The sex of this individual was not determined because, macroscopically, it is impossible to perform a reliable estimation at such a young age, or more precisely before adolescence, when the development of sexual dimorphism in the skeleton occurs (Scheuer and Black 2000). 
Table 27.1. Age at death estimation based on the measurements of the long bones

\begin{tabular}{lllll}
\hline Bone & Measurement & Author & Size $(\mathrm{mm})$ & Age at death (years) \\
\hline Right clavicle & Maximum length & Black and Scheuer 1996b* & 66.5 & $2-3$ \\
Left humerus & Diaphyseal length & Maresh, 1970* & 119.2 & 1.5 \\
Right radius & Diaphyseal length & Gindhart, 1973* & 91.6 & 1.5 \\
\hline
\end{tabular}

* These works were cited in Scheuer and Black (2000)

The identification of a severe traumatic lesion on the frontal bone, with a length of about $4 \mathrm{~cm}$, occurred during the gluing of the cranial bone pieces. The area shows irregular surfaces and signs of bone remodelling which indicate an ante mortem lesion (Fig. 27.3). Besides, an increasing thickness near the orbit and on the orbital surface of the right zygomatic bone was also noticed (Fig. 27.4). These facts were confirmed by the images obtained by 3D$\mathrm{CT}$, where different bone densities between the area affected by the lesion and the other parts of the bone can be identified (Fig. 27.5).

\section{Discussion}

Studying trauma in bones from ancient populations gives us information about occupation, personal relationships, mortuary behaviour, accidents, subsistence and trauma treatment (Roberts 2000; Lewis 2007). Brasili et al. (2004) pointed out that from the type and degree of repair of the lesion it is possible to identify its etiology and possible applied treatments. Furthermore, since

'children were involved in many aspects of life within a community, and performed many subsistence and occupational activities, evidence for trauma in their remains helps to unravel questions such as the age of apprenticeship, child abuse, parental care, the home environment and, in case of peri-mortem cuts during autopsy, the development of paediatrics' (Lewis 2007, 169).

In Augusta Emerita, among the human remains recovered from Grave A 33, was an inhumed child that shows a cranial trauma. This individual dates from the 1 st to the 2 nd century $\mathrm{AD}$, and was around 3 years old at the moment of death. The injury is located in the frontal and right zygomatic bones, and may have resulted in a primary brain lesion. Most certainly there was also a cutaneous wound. The edges of the bone lesion show signs of remodelling which, according to the medical experience of one of the authors [J. R.], suggested a survival period of between 3 weeks and 2 months. The location of the fracture, just above the orbit, and the involvement of the zygomatic area indicate that there was probably some degree of eye involvement and vision loss on the right eye. It is unlikely that vision loss occurred as a consequence of neurological damage. Despite the fact that immediate death did not occur, the trauma

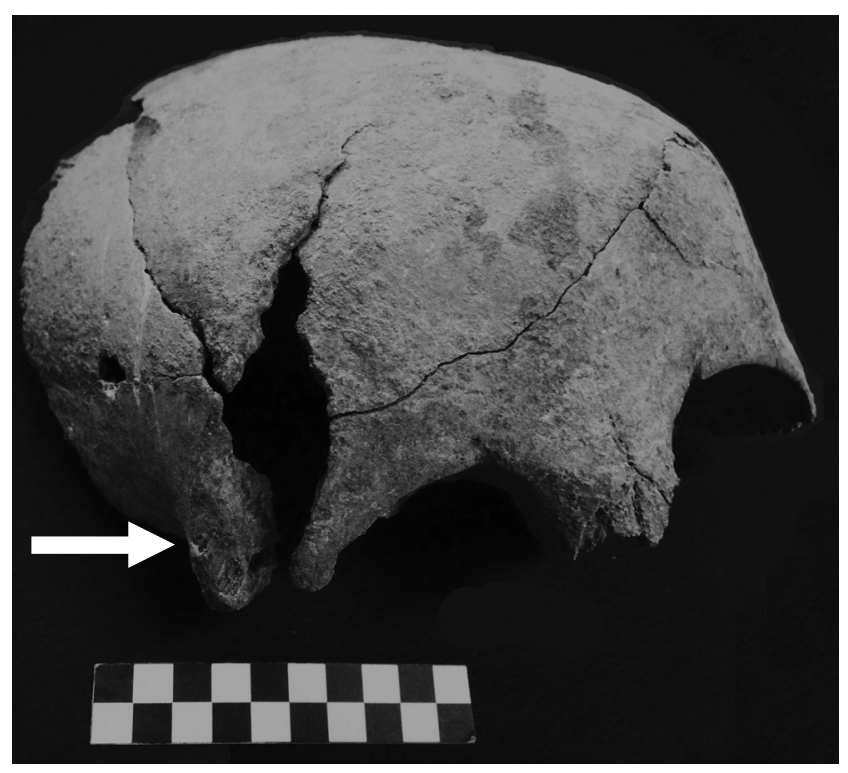

Fig. 27.3. Frontal bone in right antero-lateral view showing the fracture with bone remodelling on the edge of the lesion

certainly caused some degree of unconsciousness or coma. It is also very likely that small pieces of bone, resulting from the impact, provoked the tearing of the dura mater, putting the brain in direct communication with the skin and opening an entrance to micro-organisms. In open or compound fractures, the exposure to microorganisms was obviously a danger in antiquity due to the risk of infection (Roberts 2000), as in this case. Thus, an infection of the wound with progression to the meninges and adjacent brain was most certainly a complication and probably another factor contributing to the child's death.

A careful observation did not identify any signs of surgery in the frontal bone. However, the Romans had the medical knowledge to treat cranial fractures as can be seen on documents from antiquity (see Jackson 2005; Kshettry et al. 2007). These documents contain descriptions of head surgery, including by trepanation, to treat 'direct or indirect trauma, caused by accidental injuries or battle wounds' (Jackson, 2005). There is an interesting case of a trepanation made on a hydrocephalic child who was 5-6 years old, dated from the end of the 1st century or the start of the 2nd century AD, on the site of the ancient town of Fidenae, near Rome 


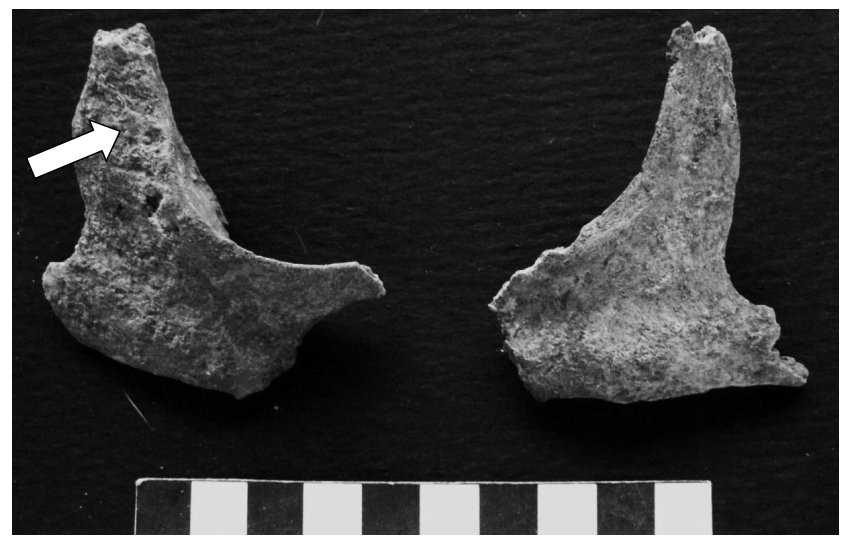

Fig. 27.4. The right zygomatic depicts an increase in the thickness near the orbit in comparison to the left one

(Mariani-Constantini et al. 2000). Several burials with medical instruments (e.g. Bejarano Osorio 2002; Márquez Pérez 2006) and epigraphic sources were found in Augusta Emerita, with the name and occupation of the person (e.g. Sanabria Escudero 1964). These finds indicate the presence of medical practitioners in the city.

Regarding the treatment of skull fractures with skin wounds, trepanation was an option but was not considered inevitable: Celsus (VIII, 4, 10-12 in Jackson 2005) proposed an initial treatment with plasters and medicated dressing. He also recognized that ' $[a]$ fractured bone unless it is treated causes severe inflammations, and is treated afterwards with greater difficulty' (De med. VIII, 4,7 in Jackson 2005, 112). On Wounds in the Head, of Hippocrates, is 'the first manuscript of antiquity dealing with cranial trauma in such detail and clarity' (Panourias et al. 2005, 187). In this book, he said that if the major sub-cranial blood vessels were avoided, skull operations presented less risk than surgery on many other parts of the body, but infection was a constant danger (in Jackson 2005).

The survival of the child found in Augusta Emerita probably depended not only on medical assistance but also on nutritional aid, since the comatose state which emerged after the accident created feeding difficulties that could lead to malnutrition and/or dehydration and cause an earlier death. These problems represented a challenge to the carer, in particular the feeding of the child, who was probably fed artificially at some point with a tube or a bottle. Unfortunately, hitherto in Mérida no such devices have been identified. However, these bottles were found in Roman child burials from Pauvadou and Saint-Lambert, exhibited in the Musée Archéologique Municipal de Frèjus (France), and recently mentioned by Trigalet (2009) in a paper about maternity and childhood. According to literaturary sources, children were breastfed until they were 3 years old and weaning was gradual (Fildes 1986 in Dupras et al. 2001). Meanwhile, food supplements such as boiled honey or a mixture of

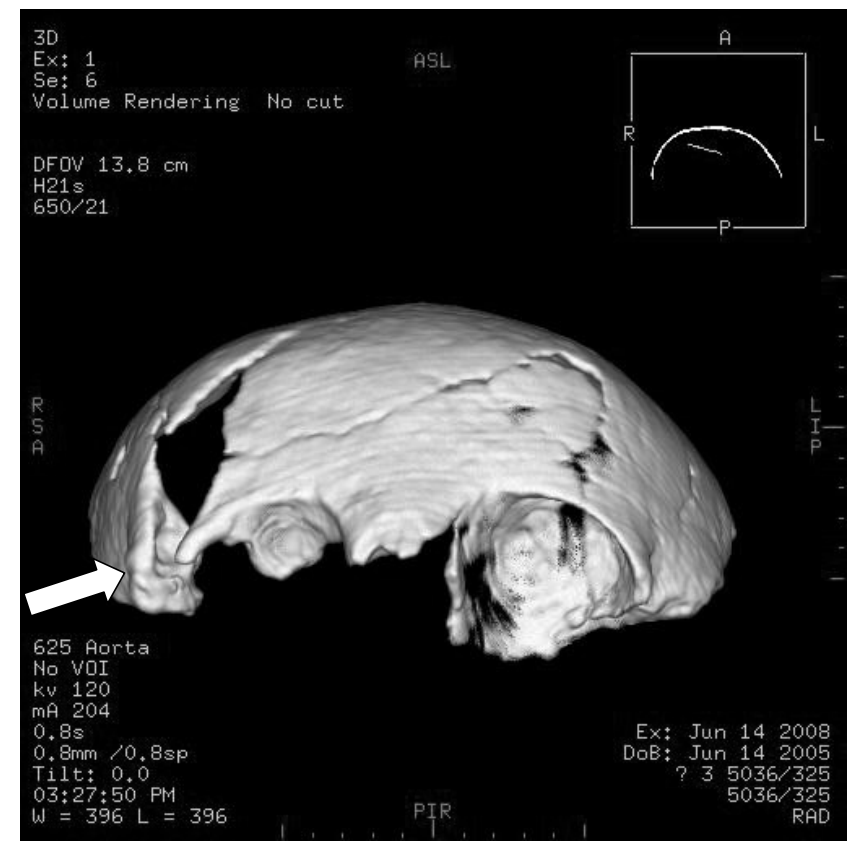

Fig. 27.5. Frontal bone observed by 3D-CT confirmed different bone densities around the area affected by the lesion

honey and goat's, cow's or sheep's milk were introduced using bottle feeding (Dupras et al. 2001).

Even nowadays cranial fractures are common in children in this age group (Lyons et al. 1999). Clinical data show that the bone affected by the lesion varies according to the age of the individual (Glencross and Stuart-Macadam 2000). Infants and young children, who are not yet able to walk, are more prone to have skull fractures (Kowal-Vern et al. 1992) as well as clavicular fractures (Glencross and StuartMacadam 2000). On the other hand, there is a prevalence of limb fractures when children become ambulatory (Cheng and Shen 1993). Today this kind of accident is more common in boys in the proportion of 1.2 to $1.5-1$ (Towner and Scott 2008).

In Roman society, child mortality was high. Rawson $(2003,341)$ points out that in the age group of birth to 5 years old the mortality rate was probably nearly $50 \%$. Nowadays, according to UNICEF (2009), this rate is $68 \%$ worldwide and $6 \%$ in industrialised countries. After diseases, trauma was the second cause of death (Coulon 2004). Based on Roman sources, Laes (2004) gives a picture of the kind of accidents affecting children, e.g. falls, accidents with chariots on crowded streets, sporting activities at the gymnasium or drowning in a river or swimming pool.

\section{Conclusions}

The observation of the skull of the child from Augusta Emerita, revealed a severe cranial trauma with signs of bone 
remodelling. Given the characteristics of the bone lesion and the possible consequences of the accident on the child's health, we estimate his or her survival for a period of between 3 weeks and 2 months. Survival for such a long time after such a violent head trauma could only have been possible with a relatively high level of care and assistance.

From a medical point of view the cause of death may have been multifactorial: trauma with direct brain injury was the initial mechanism followed by coma, or at least some mental status disturbance. It is impossible to know if the child was assisted by a Roman healer. However, it is known that the Romans had the medical knowledge, namely surgery, to deal with cranial trauma such as the case described here. This study also illustrates the importance of a multidisciplinary dialogue to understand the history of disease and medicine during the study of skeletons from past populations.

\section{Acknowledgements}

Our gratitude is due to the following institutions: the Consorcio de Mérida, Spain, Clínica Universitária de Imagiologia, University of Coimbra Hospital and Fundação para a Ciência e a Tecnologia, both in Portugal. We would also like to thank Dr Mary Lewis, Professor Demetrios Michaelides and to the participants of the Medicine in the Ancient Mediterranean World for their suggestions.

\section{Bibliography}

Bejarano Osorio, A. M. 2002: 'Nuevas aportaciones al conocimiento de la medicina y farmacéutica en la ciudad de Augusta Emerita', Mérida excavaciones arqueológicas 2000 6, Mérida, 397-421.

Blondiaux, G., Blondiaux, J., Secousse, F., Cotten, A., Danze, P.-M. and Flipo, R.-M. 2002: 'Rickets and child abuse: the case of a two year old girl from the 4th century in Lisieux (Normandy)', International Journal of Osteoarchaeology 12, 209-15.

Brasili, P., Bianchi, E. and Ventrella, A. R. 2004: 'Traumatic events and life-style in Ancient Italian populations', Collegium Anthropologicum 28(1), 179-91.

Cheng, J. C. Y. and Shen, W. Y. 1993: 'Limb fracture pattern in different pediatric age groups: a study of 3,350 children', Journal of Orthopaedic Trauma 7, 15-22.

Cook, D. C. and Powell, M. C. 2006: 'The evolution of American paleopathology', 281-322 in J. E. Buikstra and L. A. Beck (eds), Bioarchaeology: the Contextual Analysis of Human Remains, Amsterdam.

Coulon, G. 2004: L'enfant en Gaule Romaine, Paris.

Dupras, T., Schwarcz, H. P. and Fairgrieve, S. I. 2001: 'Infant feeding and weaning practices in Roman Egypt', American Journal of Physical Anthropology 115, 204-12.
Glencross, B. and Stuart-Macadam, P. 2000: 'Childhood trauma in the archaeological record', International Journal of Osteoarchaeology 10, 198-209.

Jackson, R. 2005: 'Holding on to the health? Bone surgery and instrumentation in the Roman Empire', 97-119 in H. King (ed.), Health in Antiquity, London.

Kowal-Vern, A., Paxton, T. P., Ros, S. P., Lietz, H. Fitzgerald, M. and Gamelli, R. L. 1992: 'Fractures in the under-3-year-old age cohort', Clinical Pediatrics 31, 653-9.

Kshettry, V. R., Mindea, S. A. and Hunt Batjer, H. 2007: 'The management of cranial injuries in antiquity and beyond', Neurosurgical Focus 23(1), 1-8.

Laes, C. 2004: 'Children and accidents in Roman Antiquity', Ancient Society 34, 153-70.

Lewis, M. 2007: The Bioarchaeology of Children: Perspectives from Biological and Forensic Anthropology, Cambridge.

Lyons, R. A., Delahunty, A. M., Kraus, D., Heaven, M., McCabe, M., Allen, H. and Nash, P. 1999: 'Children's fractures: a population based study', Injury Prevention 5, 129-32.

Mariani-Constantini, R., Catalano, P., Gennaro, F., Tota, G. and Angeletti, L. 2000: 'New light on cranial surgery in ancient Rome', The Lancet 355, 305-7.

Márquez Pérez, J. 2006: Los Columbarios: arquitectura y paisaje funerario en Augusta Emerita (Ataecina: colección de estudios históricos de la Lusitania, 2) Mérida.

Panourias, I. G., Skiadas, P. K., Sakas, D. E. and Marketos, S. G. 2005: 'Hippocrates, a pioneer in the treatment of head injuries', Neurosurgery 57, 181-9.

Rawson, B. 2003: Children and Childhood in Roman Italy, Oxford.

Roberts, C. 2000: 'Trauma in biocultural perspective: past, present and future work in Britain', 337-56 in M. Cox and S. Mays (eds), Human Osteology in Archaeology and Forensic Science, London.

Rühli, F. J., Lanz, C., Ulrich-Bochsler, S. and Alt, K. W. 2002: 'State-of-the-art imaging in palaeopathology: the value of Multislice Computed Tomography in visualizing doubtful cranial lesions', International Journal of Osteoarchaeology 12 , 372-9.

Sanabria Escudero, M. 1964: 'La medicina emeritense en las épocas romana y visigoda', Revista de Estudios Extremeños 20 (1), 53-84.

Scheuer, L. and Black, S. 2000: Developmental Juvenile Osteology, London.

Silva, F. C., Pérez, J. M., Rosa, J. and Santos, A. L. 2008: 'Cranial trauma on a child from a double Roman burial at Augusta Emerita, Spain', Paleopathology Association: scientific program \& abstracts. 17th European Meeting of the Paleopathology Association, 25-7 August 2008, Copenhagen, Denmark. Supplement to the Paleopathology Newsletter, 62.

Towner, E. and Scott, I. 2008: 'Chapter 1. Child injuries in context', 1-28 in M. Peden, K. Oyegbite et al. (eds), World Report on Child Injury Prevention, Geneva.

Trigalet, V. 2009: 'Maternité et petite enfance', Histoire antique 41, 64-73.

Ubelaker, D. 1989: Human Skeletal Remains: Excavation, Analysis, Interpretation, Washington.

UNICEF 2009: http://www.unicef.org/index.php. 